\title{
The simple present and the simple past in the scientific journal article: a diachronic perspective
}

David Banks

\section{(2) OpenEdition}

1 Journals

Electronic version

URL: http://journals.openedition.org/asp/726

DOI: $10.4000 / a s p .726$

ISBN: 978-2-8218-0402-9

ISSN: 2108-6354

\section{Publisher}

Groupe d'étude et de recherche en anglais de spécialité

\section{Printed version}

Date of publication: 1 December 2006

Number of pages: 119-135

ISSN: 1246-8185

\section{Electronic reference}

David Banks, "The simple present and the simple past in the scientific journal article: a diachronic perspective", ASp [Online], 49-50 | 2006, Online since 10 February 2010, connection on 22 March 2021. URL: http://journals.openedition.org/asp/726 ; DOI: https://doi.org/10.4000/asp.726

This text was automatically generated on 22 March 2021.

Tous droits réservés 


\title{
The simple present and the simple past in the scientific journal article: a diachronic perspective
}

\author{
David Banks
}

\section{Corpus}

1 This study ${ }^{1}$ considers the uses of the simple present and simple past verb forms in the scientific journal article over a comparatively long period of time. It attempts to show how the changes in tense use correspond to changes in the scientific context. In order to do this, I shall use a small corpus which has been analysed manually. The corpus consists of a selection of articles from the Philosophical Transactions of the Royal Society, which was founded in 1665, and still exists, although since 1997 it no longer publishes primary research, this role having been transferred to another of the Royal Society's publications (Atkinson 1999). The corpus is made up of thirty articles; two were selected from the year 1700, and two at twenty-year intervals up to 1980. For each year in question, one of the articles is from the physical sciences (basically physics and chemistry), and one from the biological sciences (mainly biology and zoology but including medicine and palaeontology). The corpus thus constituted has a total of 126,555 words and 9,680 finite clauses. The use of tenses has previously been studied from a synchronic point of view (e.g., Malcolm 1987, Salager-Meyer 1992, BurroughBoenisch 2003), but the few diachronic studies of scientific writing which exist (Bazerman 1988, Gross 1996, Gross et al. 2002, Atkinson 1999, Valle 1999) do not consider this question in any detail.

2 The general picture which emerges from study of this corpus is that in 1700 the physical sciences were already experimental, the intellectual revolution which had produced what was then known as the "experimental philosophy" having taken place in the second half of the seventeenth century (Jones 1961). The biological sciences were, however, descriptive, and they were to remain so until the middle of the 
nineteenth century, which thus constitutes a turning point. It is only from the middle of the nineteenth century onwards that the biological sciences begin to be experimental, and from that date experimental and descriptive articles continue side by side. A second turning point occurs at the beginning of the twentieth century, when, in the physical sciences, mathematical modelling takes on particular significance. In the course of the twentieth century mathematical calculation and the modelling of physical phenomena are frequently as important as the experiment itself.

theoretical background to the study presented here is that of Systemic Functiona Linguistics (Halliday \& Matthiessen 2004, Banks 2005), but I hope that it is written in such a way that it will be easily comprehensible to those less familiar with that theoretical approach.

\section{General Results}

4 Table 1 gives the percentages of simple present and simple past forms as a percentage of the total number of finite verb forms for each of the articles in the corpus. The percentage includes both active and passive voice. Thus for the 1700 article in the physical sciences $74 \%$ of the finite verbs are simple present, and $12 \%$ are simple past. The remaining $14 \%$ are made up of verb forms including aspect markers (progressive or perfective) or modal auxiliaries.

Table 1. Percentages of verbs in the simple present and simple past

\begin{tabular}{|c|c|c|c|c|}
\hline & \multicolumn{2}{|c|}{ Physical Sciences } & \multicolumn{2}{|c|}{ Biological Sciences } \\
\hline & Present & Past & Present & Past \\
\hline 1700 & 74 & 12 & 12 & 81 \\
\hline 1720 & 21 & 72 & 67 & 6 \\
\hline 1740 & 53 & 4 & 57 & 20 \\
\hline 1760 & 42 & 37 & 74 & 8 \\
\hline 1780 & 62 & 14 & 64 & 20 \\
\hline & & & & \\
\hline 1800 & 26 & 52 & 70 & 11 \\
\hline 1820 & 53 & 29 & 30 & 46 \\
\hline 1840 & 28 & 44 & 64 & 13 \\
\hline 1860 & 40 & 39 & 64 & 13 \\
\hline 1880 & 56 & 25 & 21 & 62 \\
\hline 1900 & 63 & 18 & 36 & 43 \\
\hline 1920 & 56 & 28 & 72 & 11 \\
\hline 1940 & 60 & 18 & 73 & 6 \\
\hline 1960 & 75 & 1 & 56 & 25 \\
\hline 1980 & 58 & 23 & 58 & 22 \\
\hline
\end{tabular}

5 These figures show that the present is more frequent than the past in 12 out of 15 physical articles and in 11 out of 15 biological articles. Otherwise the figures seem to be fairly variable, although it is possible to see some stabilization from 1880 onwards in the physical articles, and from 1920 onwards in the biological articles. From those dates the use of the present tense ranges from $55 \%$ to $75 \%$, whereas it had previously varied from $21 \%$ to $74 \%$ for the physical articles, and $12 \%$ to $74 \%$ for the biological articles. From those same dates, the past is always used with a frequency of less than $30 \%$, whereas for the physical articles it had previously ranged from $4 \%$ to $72 \%$, and for the biological articles from $6 \%$ to $81 \%$. 
I will now consider the functions for which these two verbs forms are used.

\section{Description of an experiment}

7 Experiments are usually described in narrative form, and this leads to the use of the past. Since the physical articles were experimental from the very beginning of this period, the corpus supplies examples of this from 1720 to 1980.

1....I took the Flasks out of the hot Water, and pouring that which held the Water into a Cylindrick Vessel that had three Pints of cold Water in it, I did at the same time plunge the Flask with Mercury into another Cylindrick Vessel containing also three Pints of cold Water, and observ'd which of the cold Waters was most heated in the following manner. (Desaguliers 1720) ${ }^{2}$

2. Experimental pumping was repeated to determine an optimum pumping rate. In one experiment, a sample of fluorescent $\mathrm{CaWO}_{4}$, powdered finer than $2 \mu \mathrm{m}$, was placed on top of the lunar simulant material to see if the selected pumping rate caused any significant diffusion of the material. A methyl cellulose millipore filter with a pore size of $0.22 \mu \mathrm{m}$ was placed on the downstream side of the screen, and, after the experiment, examined by electron microscope to detect any $\mathrm{CaWO}_{4}$ particles. (Horai 1980)

8 Since the biological sciences only became experimental at a much later date, there are no examples in the earlier articles, but this function of the past is to be found in the biological articles for 1820, 1860, 1900, 1920, and 1980 .

3. In the spring of 1817 , two oak trees, of nearly the same age, and growing contiguously in the same soil, were selected each being somewhat less than a century old. The one was deprived of its bark, to as great an extent as the inexperience of my workmen permitted me to have done without danger to them, and it was then suffered to remain standing. The other tree was felled, and, in the usual manner, immediately stript of its bark; and the trunk was then removed to a situation in which it was securely protected from the sun and rain. (Knight 1820) 4. For studies of the cuticle structure, fragments of exoskeleton were removed both from intaglios and from exuviae, broken cleanly across to give transverse sections. These were etched in saturated solutions of EDTA (disodium salt) before mounting for scanning electron microscopy (s.e.m.). Etching was controlled by observation under a high power binocular microscope. Etch times varied between 5 and $35 \mathrm{~min}$. Fragments of visual surface from post-ecdysial eyes were similarly treated, but in one the cuticle was entirely dissolved away and the internal mould examined (figures 46, 47). Whole eyes were removed from intermoult specimens. They were then trimmed into small blocks with a diamond blade of $1 \mathrm{~cm}$. radius. (Miller 1980)

Knight's 1820 article is historically interesting in that it is the earliest experimental article in the biological sector, although it will be noted that this experiment is not in a laboratory situation.

There are however two ways of presenting the experiment other than as a narrative. The first of these is to present it as a general process, that is, one which is in general practice, or which has at least been repeated on a number of occasions. In this case it is the present which is used. It is not the simple fact of repetition that leads to this function, as can be seen from example 2 above. It is rather the fact that the experiment is presented as something repeated and hence, presumably, repeatable. In the physical sciences, examples of this occur throughout the period considered, though they seem to disappear in the twentieth century, where the only example after 1900 occurs in the 1980 article. 
5. If, on the other hand, the three last experiments are made with the minus, instead of the plus electricity, the appearances, and consequently the reasoning upon them, are inverted: for the plus appearance in that case, must be owing to the tendency of the fluid from the earth, air, and other neighbouring bodies, towards the opposite side of the glass, where the power acts, which causes the minus appearance. (Wilson 1760)

6. If a small quantity of a gas, $\mathrm{A}$, is mixed with another gas, $\mathrm{B}$, and the mixture passed along a tube, the sides of which completely absorb A, to find what quantity of A emerges from the tube with B. (Townsend 1900) of presenting the experiment as a general process is much less frequent in the biological articles, although there are occasional examples.

7. For the preparation of this substance the original resin is coarsely powdered and extracted with cold alcohol, in order to remove, as far as possible, the syncoretin. The undissolved residue is then exhausted with boiling alcohol. The several solutions thus obtained are filtered and allowed to cool, when a white deposit is formed, which generally shows but little indication of crystalization. (De la Rue 1860)

second way in which the experiment can be presented other than as a narrative, is that of presenting it as a recipe. Once again, this leads to the use of the present rather than the past. This strategy tends to be used for experiments of a researcher other than the author himself. It is usually introduced in the context of a narrative in the past, with a switch to the present for the description of the experiment itself in the form of a recipe. Although the strategy is not frequent, it occurs spasmodically in the physical articles from 1760 to 1900, and in the biological articles from 1860 to 1900.

8. PROFESSOR LICHTENBERG, of Gottingen, some time ago made an experiment upon the electrophorus, an account of which was first received in London towards the latter end of the year 1777. [...] In brief, the experiment is as follows:

The electrophorus, that is, a plate of some resinous substance, as sulphur, rosen, gum-lac, \&c. is first excited, either by rubbing, or otherwise; then a piece of metal of any shape at pleasure, as, for instance, a three-legged compass, a piece of brass tube, or the like, is set upon the electrophorus; and to this piece of metal, so placed, a spark is given of the electricity contrary to that of the plate. (Cavallo 1780)

9. The method of the experiments, as suggested by Professor STOKES (British Association Report, 1862), is as follows: A prism is cut from a piece of spar, and the position of its faces with reference to the cleavage faces carefully determined. The prism is mounted on a spectrometer, and the collimator adjusted so that the rays of a definite wave length falling on the prism are parallel, the edge of the prism being parallel to the axis of revolution of the reading telescope. (Glazebrook 1880)

The use of the phrase is as follows here introduces the recipe format. Although this strategy is most frequently used for other researchers, this is not invariably the case.

10. When working with the first form of apparatus the experiments were conducted in the following manner: - The tube $\mathrm{A}$ is raised to a potential of 80 volts positive, and the quadrants to which the electrode is joined are insulated. The stream of air from the gasometer is thus allowed to pass through the apparatus, and, when the velocity is steady, the coil working the bulb is turned on for a fixed time (20 seconds generally) and a deflection of $n_{1}$ divisions is obtained on the electrometer scale. (Townsend 1900)

These two strategies, expressing the experiment as a general process or as a recipe, are rare in the twentieth century with a single example in 1980 appearing in the sample. 
It is interesting to note the points at which authors switch from one of these verb forms to the other in the course of describing an experiment. Thus, in example 11, Davy, in 1820 , switches from the past to the present; this occurs at a point where he moves from the action of the experiment itself, expressed in the past, to the features of the products involved, expressed in the present.

11. In the course of my experiments to ascertain the composition of fulminating platinum, I treated it with nitrous acid, and thus procured, as I have elsewhere stated, a grey oxide of platinum, which has not yet been described. It may be obtained by adding strong nitrous acid to fulminating platinum, boiling it to dryness, and exposing the dry mass to a heat just below redness, so as to expel all the nitrous acid. The oxide of platinum remains. It is to be finely pulverized and boiled, first in pure water, and then in a weak solution of caustic alkali to separate to last portions of acid, which adhere with great tenacity to it. It is now to be well washed and dried at a heat not exceeding that of boiling mercury. (Davy 1820)

Later in the same article, Davy travels in the opposite direction, changing from the present to the past; here, the more general statements introduced by the if-clause, in the present, are followed by more specific statements, in the past.

12. If the oxide is mixed with powdered glass and fused, a glass is obtained of a dull brown colour. The oxide is readily reduced by moistening it with oil of turpentine, and heating it moderately; or by exposing it to a dull red heat in the atmosphere; but it requires a strong red heat to reduce it in close vessels. Some of the oxide which had been well dried, first on a hot sand bath, and then exposed to a heat just below redness, on a slip of platinum, was decomposed in very small green glass retorts, over mercury. In two experiments in which I used 7 grains of the oxide, I obtained in each instance 6 grains of platinum, and 2.1 cubic inches of oxygen, the thermometer being at $60^{\circ}$ and barometer $30^{\circ}$. I found also in the necks of the retorts, a slight trace of a fluid that reddened litmus paper, and had an odour similar to that of nitrous acid. (Davy 1820)

17 In Townsend's 1900 article the specific experiment is narrated in the past, but a whenclause introduces more general statements in the present. In this example, the passage between the two is somewhat eased by the presence of a form with progressive aspect, which perhaps might be seen as triggering the following simple present forms.

13. In order to obtain a uniform stream of air, the tube, $G$, was connected to a gasometer, and the velocity of the gas along the tubes, $\mathrm{T}$, could be calculated by observing the rate at which the cylinder of the gasometer fell. When the bulb is giving out rays, the gas, as it passes the aluminium window, becomes a conductor, and the ions are carried with the stream into the tubes $T_{1}$. In passing through these tubes some of the ions are discharged by the sides, and the rest on coming into the field of force (caused by the difference of potential of 80 volts between the electrode and the tube C) are removed from the gas. (Townsend 1900)

Dawson, also writing in 1900, is another writer who passes from past to present to show a passage from specific to more general points.

14. It seemed at first possible that excessive swelling by Eau de Javelle might have caused this apparent bursting of the filaments, but the study of sections mounted in pure water and of hardened material showed the phenomenon to be quite normal. In sections of older tubercles the thicker filaments crossing the cortex are no longer to be seen, but those in the main tissue of the tubercles persist until decay has set in. (Dawson 1900)

The beginning of a results and discussion section is perhaps a precise example of the move from specific to general, and perhaps an attempt on the author's part to give 
general validity to his results. Desaguliers, in 1720 , provides an early example of this, though one can note the new paragraph at the point at which the verb form changes.

15. The Thermometer being again put into the first vessel fell 4 degrees, and afterwards again into the last it rose almost 3 degrees.

This shews that more heat is communicated by warm Mercury, than by an equal Bulk of Water equally warm'd; and therefore that there is more matter in the Mercury; but how much more matter there is in the Mercury is not determin'd by this Experiment alone. (Desaguliers 1720)

Wilson, in 1760 , passes from present to past, and back to present again, in a very short space of time, showing that specific and generic functions can dovetail, and an author can pass back and forth between the two.

16. It is to be observed here, that the plus appearance in the poker was caused by that portion of the fluid; which was driven off from the outside of the bottle, by the repulsive force of the fluid conveyed into the bottle. And this confirms the reasoning upon the remarkable experiments related in the treatise published by Dr. Hoadly and myself. (Wilson 1760)

Duffield, in 1920, is peculiar, in that his switch from past to present occurs in midsentence, a triumph of function and semantics over form!

17. A light paper vane was pivotted upon a vertical axis $60 \mathrm{~cm}$. above a horizontal arc, so that the rising convexion currents caused it to turn, the number of revolutions of the vane in 1 minute providing a measure of their velocity. Arcs of constant length and varying current were employed and the mean curve $C$ in fig. 21 was obtained as the result of a number of experiments, whence it is clear that over the range 2 to 10 ampères there is an increase in the velocity of the convexion currents. For a given curvature of pole the suction upon it is proportional to the square of the velocity of the air moving past it, the curve D has therefore been drawn with ordinates proportional to the square of those of curve $C$, but on a different scale, it represents, therefore, the pressure effect of the convexion currents. (Duffield 1920)

\section{Description of equipment}

The second major function which needs to be considered is that of the description of equipment. Here the date of 1900 seems to mark a watershed. From 1900 onwards equipment is usually described using the past, so that what is presented is a narrative of the construction of the experiment.

18. The movable parts of the apparatus were completely enclosed in a box, B, with a glass top to prevent disturbance from air currents in the room, and appropriate windows and holes were made in it to enable observations to be made. The torsion fibre was enclosed in a vertical tube. A lens focussed an image of the arc upon a screen to facilitate the measurement of the arc-length. (Duffield 1920)

However, although this is usual in the twentieth century there are occasional counterexamples. ${ }^{3}$

19. A retangular parallelapiped piece of copper, $1.2 \mathrm{~mm} \times 3.5 \mathrm{~mm} \times 9 \mathrm{~mm}$, with a hole containing the thermocouple junction drilled on one of the two end surfaces, is embedded into a groove, $1.2 \mathrm{~mm}$ deep and $3.5 \mathrm{~mm}$ wide, cut on the inner surface of the heater along its length, and tightened to the heater by a stainless steel screw. As the thermocouple junction is thus connected to the heater by thermally conductive metals, the junction remains isothermal to the heater's inner surface. (Horai 1980) 
is isually the present that is used, and this is frequently associated with an interatextual reference, as in the reference to "fig. 1 " in this comparatively early, 1780 , example.

20. The principal part of this instrument is a glass tube CDMN, cemented at the bottom into the wooden piece $\mathrm{AB}$, by which part the instrument is to be held when used for the atmosphere, and it also serves to screw the instrument into its wooden case ABO, fig. 1 when it is not to be used. The upper part of the tube CDMN is shaped tapering to a smaller extremity, which is entirely covered with sealing wax melted by heat, and not dissolved in spirits. (Cavallo 1780)

Any corpus of natural language texts will throw up its quota of curious examples. The following example is one such, where the description of the equipment, which begins, as one would expect for a 1980 article, in the past, switches to the present.

21. Six thermocouples, labelled respectively $\mathrm{L}_{1}, \mathrm{~L}_{2}, \mathrm{M}_{1}, \mathrm{M}_{2}, \mathrm{U}_{1}$ and $\mathrm{U}_{2}$, were attached to the core tube, the lowest, $\mathrm{L}_{1}, 11.43 \mathrm{~cm}$ from the lower and of the core tube while the others were separated by $3.81 \mathrm{~cm}$. Four thermocouples $\mathrm{O}_{1}, \mathrm{O}_{2}, \mathrm{O}_{3}$, and $\mathrm{O}_{4}$, are attached to the heater at $5.08,7.62,10.16$ and $15.24 \mathrm{~cm}$ respectively from the upper and of the heater (see figure 6). As the heater is $20.32 \mathrm{~cm}$ long, thermocouple $0_{3}$ is equidistant from the upper and lower ends of the heater. To determine the thermal conductivity at one of the core-tube's thermocouple positions, the heater position is adjusted so that thermocouple $\mathrm{O}_{3}$ is at the same level as the core-tube's thermocouple at which the thermal conductivity is to be determined. (Horai 1980)

might speculate that there is a change from constructive to descriptive mode, but the parallelism of the phrases "six thermocouples ... were attached" and "four thermocouples ... are attached" militate against this ad hoc explanation. One might again speculate that the intratextual reference, "see figure 6", triggers the change, but this seems insufficient to warrant the change involved. Perhaps it must just be accepted that natural language will provide some examples which, individually, resist attempts at explanation.

\section{Description of phenomena}

In the biological sciences, the observation and description of phenomena might be considered the biological equivalent of the experiment in the physical sciences. This concerns notably fauna and flora in biology, but also the description of fossilized remains, for example in palaeontology. The commonest form used throughout the period is the past, the observation and description being presented as a narrative.

22. In this process the tail, which was similar to that of a cock, first appeared after moulting. In the following year, she moulted again, and produced the same features. In the third year she did the same: at the same time she had spurs similar to those of a cock. She died in the following winter during the hard frost, namely, in the winter 1775/6. She never bred after this change in her plumage. (Hunter 1780)

23. The remaining 356 specimens, which showed no distortion, were by no means perfect. Of these, 186 were fractured or badly weathered. In many cases the fracture involved loss of a character, and so the specimen had to be rejected, while in other cases the specimen could be used. (Joysey 1960)

However, less frequently, but also throughout the period, there are examples of observation and description presented as general statement.

24. The cavity of the mouth is situated as in other quadrupeds, and has two grinding teeth on each side, both in the upper and lower jaw; but, instead of incisor 
teeth, the nasal and palate bones are continued forwards, lengthening the anterior nostrils, and forming the upper part of the beak; and the two portions of the lower jaw, instead of terminating at the symphisis, where they join, become two thin plates and are continued forwards forming the under portion of the beak. (Home 1800)

25. Beneath the epicuticle is a prismatic layer of typical trilobite type and of normal thickness $(10 \mu \mathrm{m})$ for $P$. rana milleri. The large calcite crystallites are arranged with their $e$-axes normal to the surface, and the surface shows an even and regular crystal texture (figure 13). (Miller 1980)

\section{Presentation of results}

Among those functions which are perhaps not major, but still fairly significant, one might class the presentation of results. This is frequently associated with discussion of the results, and is usually expressed in the present. This is probably an attempt to give permanent validity to the results presented.

26. The four last experiments prove, that the maximum of the heating power is vested among the invisible rays; and is probably not less than half an inch beyond the last visible ones, when projected in the manner before mentioned. The same experiments also shew, that the sun's invisible rays, in their less refrangible state, and considerably beyond the maximum, still exert a heating power fully equal to that of red-coloured light; and that, consequently, if we may infer the quantity of the efficient from the effect produced, the invisible rays of the sun probably far exceed the visible ones in number. (Herschel 1800)

27. It is clear that the balance of evidence favours the conclusion that the particles responsible for the recoil are electrons. It is doubtful if we can press our results much further than this in view of the very small forces to be measured and the complex conditions under which experiments of this nature must be conducted, but the view of the mechanism of the arc which is most favoured by this research (indeed the agreement with it is remarkable, though it may be accidental) is that an oxygen atom arrives at the cathode with two positive charges of electronic magnitude, and that uncharged $\mathrm{CO}$ is formed which removes two of the four electrons, which we have already shown to be associated with the departure of each carbon atom from this pole, and which are derived ultimately from the source of current supply. (Duffield 1920)

\section{Intratextual references}

Intratextual and metatextual references are invariably in the present. This includes references to other parts of the article as well as to tables and figures in the article. This is one of the rare features to which I have found no counterexamples. However these intratextual references hardly ever occur before 1840 . The one mentioned above, in example 20, being a rare early example.

28. The apparatus when in action is represented by fig. 3 , and may be described as follows. A represents the iron wires forming the electro-magnet when the voltaic current is passed through the primary coil; C, C the secondary coil; D the bar of soft iron; e, e cups of mercury connected with the primary coil; F, F binding screws to connect the primary coil with the voltaic battery; $G, G$ binding screws attached to the ends of the secondary wire. (Gassiot 1840)

29. Figure 3 illustrates the experimental arrangement for the measurements of Apollo 15 type drill samples. The sample's core tube is $42.54 \mathrm{~cm}$ long, $2.04 \mathrm{~cm}$ in inner diameter and $2.33 \mathrm{~cm}$ outer diameter. The heater is a hollow circular 
cylinder, concentric to the core-tube, $30.23 \mathrm{~cm}$ long with inner and outer diameters of $3.56 \mathrm{~cm}$ and $4.92 \mathrm{~cm}$ respectively. (Horai 1980)

\section{Intertextual references}

31 References to other work, including citations and quotations provide a good deal of variation. The most typical case is where both the verbal process verb, and the contents cited are in the present.

30. Mr. Hamilton apprehends, that the electric particles, by their elastic force, issue directly forwards from the points, and endeavour to expand themselves; but meeting with some resistance from the air, force the wire to move backward in a contrary direction, much in the same manner that a Catherine-wheel is made to turn round in a direction, contrary to that in which small rockets affixed to its periphery discharge themselves. (Wilson 1760)

31. R. WAGNER mentions that in blood taken from the heart of some of the invertebrata - Unio and Anodonta - when the coagulating fibrin makes its appearance, blood-corpuscles are seen - often grouped necklace-like - around it. (Barry 1840)

Where the verbal process verb is in the present perfect or in nominalized form, the same strategy is followed with the contents of the previous work expressed in the present.

There are a few cases, but this is fairly rare, of a verbal process verb in the present, but with the contents of the work cited in the past.

32. The Abbé, in particular, who has taken remarkable pains to find out from whence this uncertainty arises, acquaints us, in the thirteenth letter, with his difficulties, and how much it perplexed him to see, within an hour, in the same place, and with the same instruments, the effects changed, and become altogether contrary to those he had before observed. (Wilson 1760)

33. VALENTIN, however, states that the globules in question entered into the formation of the "uniting mucous tissue." (Barry 1840)

There are also some cases of verbal process verbs in the past, but these never occur, in the corpus, earlier than 1900 , so this appears to be a twentieth century phenomenon. When this occurs, the contents is usually presented in the present.

34. From characters possessed in common by this mykoplasm and the infection tubes and filaments, FRANK concluded that they are of like origin, and are, in fact, formed by the plant itself as a means by which it conducts to the inner cells the symbiotic organisms (minute cocci) which are destined to grow there. (Dawson 1900)

35. Kahn gave equations representing the conservation of mass, momentum and energy across the ionization front and showed that there is a close analogy between combustion waves and ionization fronts. (Axford 1960)

Dawson, writing in 1900, provides a peculiar case. She includes an extremely extensive literature review, and there are numerous other references throughout her article. In these she uses all the combinations of present and past possible, even passing from one to the other as in the following example.

36. He considers the tubercles developed in these two genera to be typical of the two classes found in all the Leguminosæ, and describes in detail their respective relations to the vascular bundles of the roots, and the special characters of the inner "Bacteroid" tissue, noting in particular the absence of filaments along with Bacteroids in the cells of the tubercles of Lupinus. In accordance with BRUNCHORST, he denied the parasitic nature of the Bacteroids; indeed, he considered the 
tubercles themselves to be merely storehouses of reserve material, chiefly albuminoids and possibly also starch. (Dawson 1900)

Although the "he" of "he considers" is coreferential with the "he" of "he denied", there is a switch from present to past. One might hypothesize that it is the reference to Brunchorst that motivates this change.

\section{Mathematics}

Mathematical calculation and modelling play an important role, particularly in the physical sector, from the end of the nineteenth century onwards, with a rapid increase during the twentieth century. This introduction of mathematical discourse (O'Halloran 2005) generally uses the present, and accounts for an increase in the use of present forms in these articles.

37. The mean of the above determinations gives 93.08 at $18^{\circ} .9$ for the conducting power of pure copper. (Matthiessen 1860)

38. Important conclusions can be drawn from the graph of $G$ against $Y$. This is a parabola which touches the lines $Y=1$ and $G=25 / 8$ as shown in figure 5 , where there is also drawn the parabola $w(Y)$. Values of $M_{1}$ and $M_{2}$ and the corresponding signs of $d$ and $e$ are also indicated. The curve $G(Y)$ is closely related to the Rayleigh line in the theory of one dimensional flow with heat addition. (Axford 1960)

\section{Minor functions}

I would consider as minor functions the expression of more general narration, and historical passages on the one hand, and general statements on the other. As one would expect from more familiar (commonly called "general") genres, the first of these categories is expressed in the past.

39. Fifteen years ago, one John Potin, French-man, then Servant to my Lord Culpepper, got a fall, which caused him a heavy pain in the breast for a while. A month after, he being a shooting, a Musquet did burst in his hands, which gave so violent a recoyle against his Right side, that it made him spit blood immediately, and continued for six months. One year after he began to feel a pulsation on that side, and then he spit blood again, which continued ever since, but only in the Spring and the Fall. (Lafage 1700)

40. The correspondent's father, my friend Dr. BENNETT, F.L.S., being in London when these specimens had arrived, I dissected them in his presence, but found not any ovum in either uterus. The ovaria showed one or more enlarged ovisacs. (Owen 1880)

And the second is expressed in the present.

41. All the Papavers are Narcotick. The Esulee and Tithymali are Cathartick; tho' both these are Lactescent, yet they differ from those which are Pappescent also. All the Malva's are chiefly Emollient; The Pentaphyllous kind astringent; as are also the Plantains. (Blair 1720)

42. In the majority of species which have been examined, pigmentation in any given part of a plant is due to one anthcyanin only. There are, however, a certain number of exceptions, in which a second constituent is present - usually in small proportion. (Lawrence 1940) 


\section{Closing remarks} using the resources of the language to make choices which depend on the changing historical and scientific context in which they found themselves. This study therefore provides a specific example of the way in which language is dependent on, and conditioned by, the context in which it is produced, and the fact that the context is essential for understanding language and the way it is used.

Lafage 1700: This article is written in the third person, so it is not clear whether it was written by Lafage himself or by some other anonymous author.

Desaguliers 1720: John Theophilus Desaguliers 1683-1744. Born in France, came to England at the age of eleven. Described by the Encyclopaedia Britannica as a "British inventor".

Cavallo 1780: Tiberius Cavallo, born Naples 1749, died London 1809. Came to England in 1771.

Herschel 1800: Sir Frederick William (originally Friedrich Wilhelm) Herschel, born Hanover 1738, died Slough 1822. Came to England in 1757.

Gassiot 1840: John Peter Gassiot 1797-1877.

Matthiessen 1860: A. Matthiessen (co-author M. Holzmann).

De La Rue 1860: Warren De La Rue, born Guernsey 1815, died London 1889 (co-author Hugo Müller).

Horai 1980: K. Horai, one of six co-authors, the others being J.L. Winkler Jr., S.J. Keihm, M.G. Langseth, J.A. Fountain and E.A. West. All have institutional addresses in the USA.

Thus of thirty authors, three were born outside England (plus perhaps Matthiessen, for whom I have no information), but all were permanent immigrants to England, one of them from the age of eleven. This would seem to minimize any possible non-native speaker influence. 


\section{BIBLIOGRAPHY}

Atkinson, Dwight. 1999. Scientific Discourse in Sociohistorical Context, The Philosophical Transactions of the Royal Society of London, 1675-1975. Mahwah, NJ: Lawrence Erlbaum Associates.

Banks, David. 2005. Introduction à la linguistique systémique fonctionnelle de l'anglais. Paris: L'Harmattan.

Banks, David. 2009. "L'usage du présent et du passé simple dans l'article scientifique anglais à partir du dix-huitième siècle". In Banks, David (ed.), Le temps dans le texte de spécialité. Paris: L'Harmattan.

Bazerman, Charles. 1988. Shaping Written Knowledge, The genre and activity of the experimental article in science. Madison: University of Wisconsin Press.

Burrough-Boenisch, Joy. 2003. "Examining present tense conventions in scientific writing in the light of reader reactions to three Dutch-authored discussions". English for Specific Purposes 22/1, 5-24.

Gross, Alan G., Joseph E. Harmon \& Michael Reidy. 2002. Communicating Science, The scientific article from the 17th century to the present. Oxford: Oxford University Press.

Halliday, M.A.K. \& Christian M.I.M. Matthiessen. 2004. An Introduction to Functional Grammar, 3rd. edn. London: Arnold.

Jones, Richard Foster. 1961 [1982]. Ancients and Moderns, A study of the rise of the scientific movement in seventeenth-century England. New York: Dover.

Malcolm, Lois. 1987. “What rules govern tense usage in scientific articles?” English for Specific Purposes 6/1, 31-43.

O'Halloran, Kay L. 2005. Mathematical Discourse, Language, Symbolism and Visual Images. London: Continuum.

Salager-Meyer, Françoise. 1992. "A text-type and move analysis study of verb tense and modality distribution in medical English abstracts”. English for Specific Purposes 11/2, 93-113.

Valle, Ellen. 1999. A Collective Intelligence, The life sciences in the Royal Society as a scientific discourse community, 1665-1995. Turku: Angliana Turkuensia.

\section{APPENDIXES}

\section{Appendix 1. Corpus}




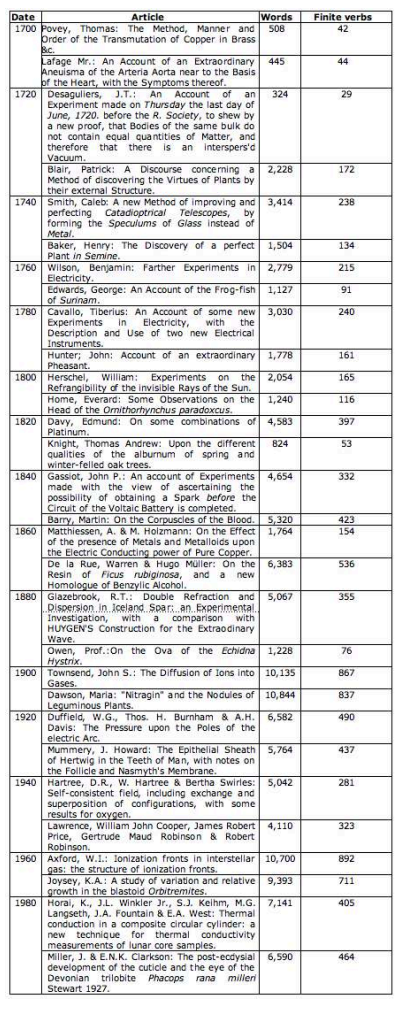

\section{NOTES}

1. This paper is a rewritten version of a paper originally presented in French at the Nouvelles Journées de l'ERLA No.6, "Le temps dans le texte de spécialité", 18-19 Nov. 2005 at Brest, and published as Banks (2009) [NDLR]. This English version was presented at the $27^{\mathrm{e}}$ Colloque du GERAS, "Cours et Corpus", 23-25 March 2006 at Lorient.

2. Highlighting of simple present and simple past forms in bold is mine throughout.

3. Some readers may wonder whether the possible presence of non-English speaking authors may affect the linguistic features used. To estimate any possible affect, notes on those authors whose names are not typically English are given below.

\section{ABSTRACTS}

The functions of the simple present and the simple past are considered in a corpus of English scientific journal articles selected from the Philosophical Transactions of the Royal Society, and covering the period 1700 - 1980. It is found that the past is used for experiments presented as narratives, but that other possibilities exist. The description of equipment is usually in the present, as are results and discussion. Intratextual references are always in the present but intertextual references are more complex. Mathematical sections, particularly important in twentieth century physics, are in the present. The uses of these verb forms mirror the changing context in which the texts were produced. 
Le présent article étudie les fonctions du présent simple et du passé simple dans un corpus d'articles scientifiques en langue anglaise, tirés du Philosophical Transactions of the Royal Society. Le corpus recouvre la période 1700 - 1980. On constate que le passé s'utilise pour les expériences présentées comme des narrations, quoique d'autres possibilités existent. La description des expériences se fait au présent, ainsi que la présentation des résultats et leur discussion. Les références intratextuelles sont toujours formulées au présent, tandis que les références intertextuelles sont plus complexes. Les sections mathématiques, particulièrement importantes dans les sciences physiques au cours du vingtième siècle, utilisent le présent. L'usage de ces formes verbales reflète l'évolution du contexte d'où ces textes surgissent.

\section{INDEX}

Mots-clés: anglais scientifique, article de recherche scientifique, linguistique diachronique, passé simple, Philosophical Transactions, présent simple

Keywords: diachronic linguistics, Philosophical Transactions, scientific English, scientific journal article, simple past, simple present

\section{AUTHOR}

\section{DAVID BANKS}

David Banks est Professeur de linguistique anglaise à l'Université de Bretagne Occidentale. Il est directeur de l'ERLA (Équipe de recherche en linguistique appliquée) et président de l'Association française de la linguistique systémique fonctionnelle (AFLSF). Il dirige un Master 2 « RédacteurTraducteur ». Il est auteur ou responsable d'une douzaine d'ouvrages et plus de cinquante articles, y compris, parmi les plus récents, Introduction à la linguistique systémique fonctionnelle de l'anglais, Les marqueurs linguistiques de la présence de l'auteur, Aspects linguistique du texte de propagande, Lexique quadrilingue de la musique, tous parus chez L'Harmattan en 2005.

David.Banks@univ-brest.fr 